\title{
Possible Sites of Therapeutic Action in Restless Legs Syndrome: Focus on Dopamine and $\alpha_{2} \delta$ Ligands
}

\author{
Andrew J. Thorpe ${ }^{\mathrm{a}}$ Andrew Clair $^{\mathrm{a}}$ Shawn Hochman ${ }^{\mathrm{b}}$ Stefan Clemens ${ }^{\mathrm{c}}$ \\ aPfizer Inc., New York, N.Y., 'b Department of Physiology, Emory University School of Medicine, Atlanta, Ga., and \\ 'Department of Physiology, Brody School of Medicine, East Carolina University, Greenville, N.C., USA
}

\section{Key Words}

Restless legs syndrome $\cdot$ Iron $\cdot$ Dopamine $\cdot$ Voltage-gated calcium channel $\alpha_{2} \delta$ ligands • Adenosine $A_{2} A$ receptor • Opioids

\begin{abstract}
Restless legs syndrome (RLS) is a common sensorimotor disorder characterized by abnormal sensations that occur primarily at rest or during sleep, which are alleviated by movement of the affected limb. The pathophysiology of RLS remains unclear, although roles for dopamine dysfunction and brain iron deficiency have been proposed. The hypothalamic A11 dopaminergic circuit is used to explain the dopamine dysfunction in RLS and the potential therapeutic actions of dopamine $\mathrm{D}_{2}$ agonists. Modulation of central and peripheral neuronal circuits may also explain the potential therapeutic sites of action of opioids, adenosine receptor ligands, and voltage-gated calcium channel $\alpha_{2} \delta$ ligands in RLS. The known and possible therapeutic benefits of these agents and their relationship to dopaminergic dysfunction in RLS are discussed in this review.

Copyright $\odot 2011$ S. Karger AG, Basel
\end{abstract}

\section{Introduction}

Restless legs syndrome (RLS) is a common disorder of the nervous system, with a prevalence of $2.1-10.0 \%$ of the overall population $[1,2]$. RLS is characterized by focal dysesthesias in the legs, otherwise referred to as abnormal limb sensations [3]. The characteristic hallmarks of RLS are sensations ranging from uncomfortable to irritating to painful. These sensations usually develop in the lower limbs together with an urge to move the affected limbs, and are felt mostly at rest and especially when attempting to sleep [3].

The clinical symptoms of RLS were first described in 1685 [4], with the term RLS introduced in 1945 by Karl Axel Ekbom [5, 6]. Two forms of RLS have been identified: primary and secondary. The primary, or idiopathic, form has a strong familial inheritable component [3] and typically appears around the mid-to-late twenties with a slow onset, although symptoms can begin at any age. The disease can fluctuate, but spontaneous long-term remissions are not usually observed in those patients with more advanced stages of the disorder. Symptoms typically worsen with increasing age, especially in patients with onset in young adulthood [3].

Andrew J. Thorpe, $\mathrm{PhD}$

Pfizer Inc.

235 East 42 nd Street

New York, NY 10017 (USA)

Tel. +1 636821 1255, E-Mail andrew.thorpe@ pfizer.com 


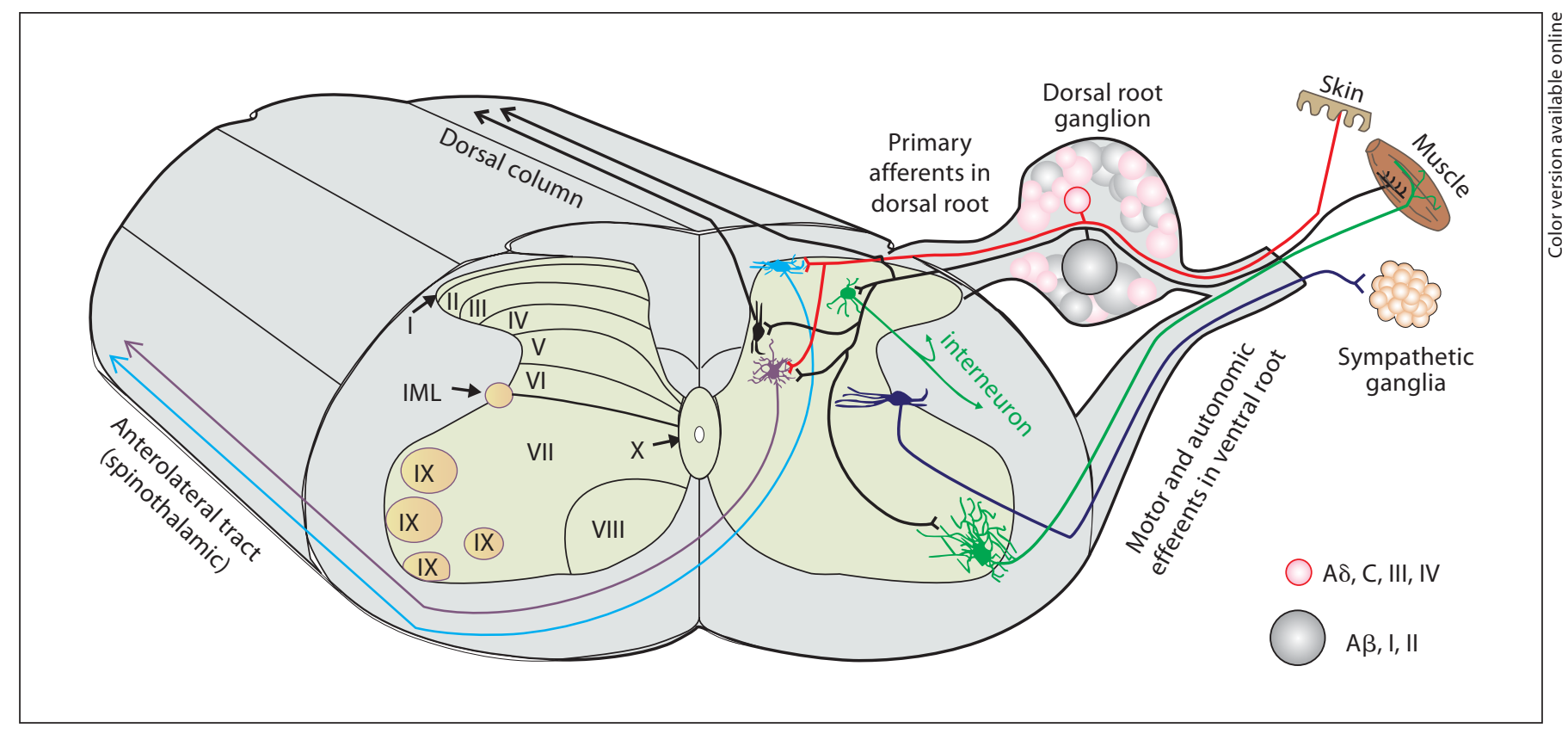

Fig. 1. The spinal cord is the gateway for information transfer between body and brain. As shown in the left half of the figure, the spinal cord is divided into anatomical layers or laminae that are divided into sensory dorsal horn (laminae I-VI), the intermediate gray (lamina VII), and ventral horn (laminae VII-IX). Laminae IX contains the various motoneuron pools (nuclei) whose axons, along with sympathetic (thoracic) or parasympathetic (sacral) preganglionic neurons located in the intermediolateral nucleus, exit via ventral roots. Sensory afferents with cell bodies located in the dorsal root ganglia project onto spinal neurons largely within the dorsal horn. Sensory afferents transmit information from receptors in the periphery for pain, temperature, and crude touch

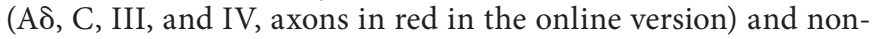
pain encoding, stretch-sensitive, and force-sensitive mechanoreceptors (A $\beta$, I, and II, axons in black). Axon tracts of the dorsal column and anterolateral tract transmit sensory information to the brain. IML = Intermediolateral nucleus. Adapted from [51]. Copyright 2007, with permission from Elsevier.
Although first identified over 300 years ago as a disorder of the nervous system with spinal cord involvement [4], the cause of RLS is still not completely known. To date, 2 predominant mechanisms underlying RLS have been proposed in some detail, namely (i) dopaminergic dysfunction [7-9] and (ii) brain iron deficiency [10-12]. As such, pharmacological intervention to date has been focused on these 2 physiological processes. Furthermore, the complex nature of RLS as a somatosensory network disorder [9] suggests that several levels of interactions occur between central and peripheral circuits in parallel [8], many or all of which may be amenable to modulation by dopamine or iron levels.

\section{Purpose and Perspective}

The aim of this review is not to delve into the possible biological causes of RLS, but rather to summarize current therapeutic approaches for the treatment of RLS, be they traditional pharmacological approaches or investigational agents. In addition, an appraisal of the mechanistic understanding of dopaminergic intervention forms the foundation of the proposed functioning of adenosine analogs, opioids, and $\alpha_{2} \delta$ ligands that are potential treatments for this disease (none are currently approved for the treatment of RLS). While numerous recent articles have highlighted the links between genetics and RLS and the role of brain iron deficiency in RLS $[12,13]$, these areas are beyond the focus of this review. Here, we examine the actions of other drug classes, including $\alpha_{2} \delta$ ligands, opioids, and adenosine-receptor ligands, and how these might be related to the effects of dopamine agonists in RLS. We posit that the therapeutic actions of $\mathrm{D}_{2}$-like agonists occur within the spinal cord and within associated peripheral afferent and efferent signaling systems (fig. 1). Using the hypothalamic A11 dopaminergic circuit as a platform, we explain the potential therapeutic actions of dopaminergics, opioids, adenosine analogs, and calcium channel $\alpha_{2} \delta$ ligands (fig. 2). It is important to note that the hypotha- 


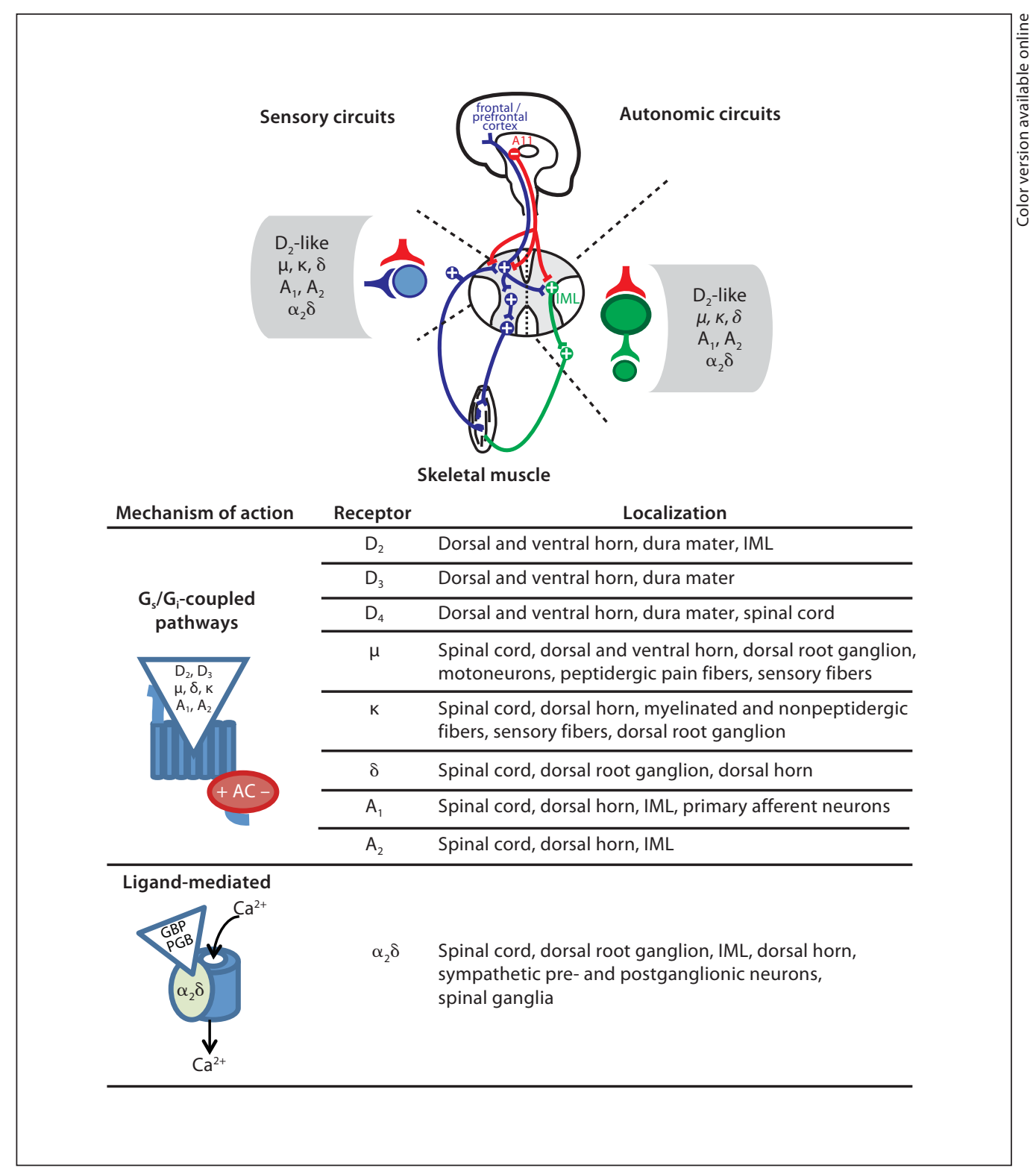

Fig. 2. Common targets of dopamine-, adenosine-, and opioidreceptor ligands in the proposed spinal/peripheral circuitry affected by dopamine. Based on the hypothesis detailed by Clemens et al. [8], dopaminergic projections descending from the A11 region of the hypothalamus project to spinal neuronal systems whose dysfunction leads to the RLS phenotype. Here, hypothalamic A11 dopaminergic neuron projections to sensory and autonomic regions of the spinal cord are shown (red). On the somatic side (left, in blue), sites for the effects of dopamine, adenosine $A_{1}$, adenosine $\mathrm{A}_{2}$, and opioid receptors have been identified and are found in the dorsal horn. On the autonomic side (right, in green), actions of dopamine and adenosine receptors have been identified on sympathetic preganglionics, and there is evidence of opioid action. $\alpha_{2} \delta$ ligands are proposed to exert actions in central circuits. Note that the effects of dopamine, adenosine, and opioid receptor pathways alter levels of cAMP through $\mathrm{G}_{\mathrm{i}}$ - or $\mathrm{G}_{\mathrm{s}}$-coupled control of adenylyl cyclase (AC), whereas $\alpha_{2} \delta$ ligands are proposed to modify the excitability of the target tissues directly by binding to voltage-gated calcium channels. $\mathrm{D}_{2}$-like, opioid, and $A_{1}$ receptors act through $G_{i}$ to inhibit $A C$ and $A_{2}$ receptors couple to $G_{s}$ to stimulate AC. Receptors/binding sites that have been shown to be expressed or function within each circuit are listed in the grey boxes (italics indicate less evidence). Dopamine receptors, $\mathrm{D}_{2}$ : [54-56, 59]; $\mathrm{D}_{3}:[54,55,57] ; \mathrm{D}_{4}:[54,55,58]$. Opioid receptors, $\mu$ : [89-91, 94, 95, 97-103]; к: [89-91, 93-95, 102, 103]; $\delta$ : [89$92,94,96,104]$. Adenosine receptors, $A_{1}:[112-115,117-122,124$, $126,128] ; A_{2}:[112,113,115,117,123,125] . \alpha_{2} \delta$ subunits: [116, 142, $144,145,147,150-152]$. GBP = Gabapentin; IML = intermediolateral nucleus; $\mathrm{PGB}=$ pregabalin. Adapted with permission from [8]. Colors refer to the online version only. 
lamic A11 dopaminergic circuit, with its projections to the spinal cord, provides the only circuit proposed to date whose dysfunction would be consistent with both an RLS phenotype and an explanation of $\mathrm{D}_{2}$-like therapeutic actions $[8,14]$. While alternate models may conceivably exist that account for the dopamine hypothesis in RLS (and the beneficial actions of dopaminergics as therapeutics), to our knowledge, none have been proposed that clearly link circuit dysfunction to the RLS phenotype. Although changes in central nervous system (CNS) dopaminergic function have been identified in other regions in association with RLS, including iron metabolism $[10,12,15,16]$, their correlation may be a secondary consequence of RLS rather than a primary causal factor.

\section{Current Treatment Approaches to RLS}

\section{Dopamine Receptor Agonists}

Dopaminergic drugs have shown efficacy as an RLS treatment in numerous large-scale clinical studies [17], and dopamine agonists improve RLS symptoms from the first day of application [18]. Currently, dopamine agonists targeting $\mathrm{D}_{2}$-like receptors (most of the current agonists have the highest affinity for $\mathrm{D}_{3}$ receptors) represent the first line of pharmacological intervention [19]. Clinical studies have shown that levodopa, pramipexole, ropinirole, lisuride, pergolide, cabergoline, and rotigotine reduce the symptoms of RLS [17]. Among these, pramipexole, ropinirole, and rotigotine are approved to treat RLS in various countries. All 3 have the highest affinity for $D_{3}$ receptors [20-22]. However, long-term use of dopamine therapy in patients with RLS has potentially serious consequences, including symptom rebound, development of compulsive disorders, and augmentation. Augmentation is the paradoxical emergence of more severe RLS symptoms, including worsening of symptoms, symptoms appearing earlier in the day, and spread of symptoms to previously unaffected body parts $[9,23,24]$. Furthermore, the ergot-derived dopamine agonists (e.g. pergolide and cabergoline) are generally not recommended for the treatment of RLS because of the rare, but serious, potential for pulmonary and cardiac fibrotic adverse events [17]. Because RLS is typically a life-long condition, alternative therapeutic targets for modulating sensory perception in RLS have been sought.

Iron

The association between iron deficiency and RLS points toward iron supplementation as a therapeutic op- tion in patients with low iron levels. In one study, oral iron showed no benefits on RLS symptoms [25]; however, another small study of oral iron therapy that used the validated International Restless Legs Study Group Severity Scale (IRLS) showed an improvement in RLS symptoms in patients with RLS and low-normal serum ferritin levels [26]. High-dose iron dextran infusion has been shown to transiently reduce RLS symptoms in patients with end-stage renal disease or with low ferritin levels [27, 28]. Intravenous iron dextran also reduced the symptoms of RLS in patients refractory to other treatments; however, the duration of effect was variable and the results of treatment were not predictable from patients' baseline characteristics [29]. Taken together, the clinical evidence suggests that restoration of serum ferritin levels with oral iron therapy may benefit some patients with RLS [30]. Adverse events of iron therapy include constipation, nausea, a potential for iron overload, and anaphylactic reactions to iron dextran $[25,29]$.

\section{Opioids}

Low- and high-potency opioids, including oxycodone, tramadol, and methadone, have shown efficacy in reducing the symptoms of RLS in short-term studies [31-33]. Opioids are frequently used off-label in patients with RLS, particularly in those refractory to dopamine agonists; however, large controlled clinical studies establishing their efficacy in RLS are lacking. Thus, opioids are typically considered only second-line treatment to dopamine agonist therapy $[17,34,35]$. Augmentation has been reported following long-term treatment with tramadol [36], along with other safety concerns with opioids, including constipation, respiratory depression, sleep apnea, and the potential for addiction $[17,37,38]$. The addiction potential of opioids coupled with their controlled regulatory status have limited their commercial development for RLS [17].

\section{Possible Alternate Approaches}

\section{Adenosine Receptor Antagonists}

Adenosine receptors have recently been proposed as potential therapeutic targets for RLS $[39,40]$. However, despite the putative links between adenosine and dopamine in motor and sensory control and their common second messenger targets, no clinical trials of adenosine receptor ligands for the treatment of RLS have been reported. Therefore, the efficacy, safety, and validity of adenosine receptor-blocking drugs as viable, novel therapies for RLS have not been established. 


\section{Clinical Efficacy of $\alpha_{2} \delta$ Ligands in Controlling the} Symptoms of RLS

Recent clinical studies have shown efficacy for gabapentin, gabapentin enacarbil, and pregabalin in reducing the sensorimotor symptoms of RLS, although none of these agents are approved for the treatment of RLS. In a small placebo-controlled study, gabapentin improved RLS symptoms, periodic leg movements during sleep, and sleep architecture in patients with RLS, most of whom had the idiopathic form [41]. Gabapentin enacarbil, a prodrug of gabapentin with improved pharmacokinetics [42], significantly improved IRLS scores, clinicianrated response to therapy, and some sleep parameters in patients with idiopathic RLS [43-46]. In a small uncontrolled study of pregabalin in clinical practice, most patients with secondary RLS and neuropathic pain reported improvements in their RLS symptoms [47]. More recent randomized, double-blind, placebo-controlled studies of pregabalin have demonstrated significant improvements in IRLS scores [48, 49], periodic leg movements during sleep [48], and sleep architecture [48] in patients with idiopathic RLS. Common side effects of $\alpha_{2} \delta$ ligands in patients with RLS include malaise, somnolence, dizziness, headache, dry mouth, and fatigue [41, 43, 44, 46, 48, 49]. Unlike dopamine agonists, symptom rebound has not been observed following withdrawal of pregabalin or gabapentin enacarbil $[49,50]$.

\section{Potential Therapeutic Sites of Action}

RLS is a disorder characterized by abnormal sensations. Therapeutically, there are multiple sites for the control of aberrant somatosensory processing prior to perception in the cortex. Those associated with spinal cord circuits are described below.

\section{A11 Dopamine, Dopamine Receptors, and Spinal}

Circuits in Relation to RLS

A concise overview of spinal cord function and its functional systems can be found in Hochman [51]. Briefly, the spinal cord is the part of the CNS that provides the gateway for information transfer between body and brain (fig. 1). It is also an integrative center for neuronal circuits that coordinate complex sensory, motor, and autonomic functions. The entire sympathetic neural output departs the CNS via convergence onto spinal sympathetic preganglionic neurons, and the entire somatosensory input from the body is first processed through the spinal cord. Moreover, the entire neural circuitry required to generate locomotion and other complex movements resides entirely within the cord.

Spinal cord function is strongly modulated by serotonin, norepinephrine, and dopamine. Dopamine is a neurotransmitter that binds to $D_{1}$-like $\left(D_{1}\right.$ and $\left.D_{5}\right)$ receptors coupled to the $G$ protein $G_{s}$ to stimulate adenylyl cyclase and increase formation of cyclic adenosine monophosphate (cAMP), leading to a facilitation of network excitability. It also binds to $\mathrm{D}_{2}$-like $\left(\mathrm{D}_{2}, \mathrm{D}_{3}\right.$, and $\left.\mathrm{D}_{4}\right)$ receptors coupled to $G_{i}$ to inhibit adenylyl cyclase and cAMP production, generally depressing network function [52]. Dopamine and all 5 dopamine-receptor subtypes can be found in the rodent spinal cord, including the dorsal and ventral horn and dura mater (fig. 2) [53-59]. Furthermore, $\mathrm{D}_{2}$ receptors have been found in the rodent intermediolateral cell column, the location of the sympathetic preganglionic neurons [56]. In comparison, in the non-human primate lumbar spinal cord, mRNA for $\mathrm{D}_{2}, \mathrm{D}_{3}$, and $\mathrm{D}_{5}$ receptors was detected with in situ hybridization without evidence of $\mathrm{D}_{1} \mathrm{mRNA}$ expression [60]. While this does not exclude the presence of spinal cord $D_{1}$ receptor protein in primary afferent terminals, this study highlights the presence of interspecies differences in expression. Overall, dopamine appears to have lower affinity for the $\mathrm{D}_{1}$-like receptors compared with the $\mathrm{D}_{2}$-like receptors, and the highest affinity for $\mathrm{D}_{3}$ receptors $[8,61]$.

A small cluster of dopaminergic neurons (A11 population) found in the dorsal-posterior hypothalamus $[8,60$, 62 ] is thought to represent the sole source of spinal dopamine in the rat [63] and the predominant source in the mouse [64]. A11 projections issue collaterals throughout the rostrocaudal extent of the spinal cord [63]. As collaterals project to sensory, motor, and autonomic regions $[53,60]$, it is likely that there could be coordinate regulation of these spinal functional systems, and consequently, a coordinate dysregulation if A11 drive was altered.

Dysfunction of the A11 region has been implicated in the pathophysiology of RLS $[8,14,60,62]$. In RLS, it is possible that the observed circadian cycling of dopamine that reaches its lowest levels in very early morning [65] is either excessively lowered (hypofunction) or has a blunted reduction (hyperfunction). In such a push-pull mechanism [9], the hypothesis of A11 hypofunctioning at nighttime in RLS assumes low dopamine release has inhibitory actions that would normally preferentially activate high-affinity $\mathrm{D}_{2}$-like receptors to reduce sensory responsiveness. The consequence of a hyporelease of dopamine then has been hypothesized to lead to a series of parallel events that disinhibit spinal cord sensory, motor, and autonomic systems $[8,60]$. Nighttime hypofunction could arise from in- 
creased circadian amplitude fluctuations with even lower dopamine levels at night [65]. Another possibility is that neurodegenerative loss of spinal dopaminergic terminals from the A11 region results in a decrease of dopamine in the spinal cord [66]. While loss is possible at the level of terminals in the spinal cord, as in the nigrostriatal dopamine system, there does not appear to be any loss of tyrosine hydroxylase-staining cell bodies in the A11 region from postmortem tissue of patients with RLS [67].

An alternate hypothesis is that the principal pathophysiology in RLS resides in a hyperfunctioning of the A11 dopaminergic pathways at nighttime. Dopamine levels fluctuate in the CNS in a circadian manner, and there is an age-dependent blunting of circadian amplitudes with age $[68,69]$. The weakened reduction and hence higher levels of dopamine at night could result in an aberrant activation of lower affinity, but 'excitatory' drive mediated by $\mathrm{D}_{1}$ or $\mathrm{D}_{5}$ receptors, even when low levels of the receptor are present [60]. Indeed, there is evidence of an altered circadian rhythmicity in dopamine metabolism in RLS [70], with an intriguing blunting of and inversion in circadian tyrosine hydroxylase expression in the sympathetic preganglionic neurons of $\mathrm{D}_{3}$-knock-out $\left(\mathrm{D}_{3} \mathrm{KO}\right)$ mice [71]. As microdialysis studies have demonstrated that spinal dopamine levels significantly decreased during rapid eye movement sleep when compared with wakefulness [72], an increased nighttime dopamine drive could aberrantly facilitate sensorimotor systems in RLS - this is consistent with the emergence of periodic leg movements and increased reflex excitability in sleep [73, 74].

All dopamine receptor subtypes are also present on afferent neurons within cell bodies in the dorsal root ganglia [75], with the highest dopamine affinity and greatest inhibitory actions in the small diameter neurons [76], and pain transmission is selectively inhibited by $\mathrm{D}_{2}$-like agonists [77]. Assuming that RLS is primarily a sensory disorder, this action alone may explain the therapeutic actions of dopaminergics completely independent of any need for central dopamine dysfunction. This would be consistent with the apparent absence of $\mathrm{D}_{2}$-like autoreceptor function on descending dopaminergic terminals [78]. The possibility of a spinal site of action is further provided by studies with the $\mathrm{D}_{3} \mathrm{KO}$ mouse. The $\mathrm{D}_{3} \mathrm{KO}$ mouse displays hyperactivity, increased locomotor activity, and hypertension $[79,80]$. This phenotype resembles features of patients with RLS $[8,81]$. Moreover, a recent study showed that both iron deficiency and $\mathrm{D}_{3}$ receptor dysfunction can mimic evoked sensory and motor symptoms in mice resembling those observed in RLS patients [82]. In the isolated spinal cord of the $\mathrm{D}_{3} \mathrm{KO}$ mouse, the effect of dopamine on spinal reflexes is converted from inhibitory to mildly facilitatory, showing that $\mathrm{D}_{3}$ receptors are involved in limiting spinal cord sensory processing [83]. Further studies are warranted to confirm these hypotheses in humans, especially in light of the apparent species-specific expression of dopamine receptor subtypes in the spinal cord [60]. Independent of the A11 being dopaminergic, as discussed above, or possibly only L-dopa-ergic $[60,78,84]$, there is little doubt that A11 stimulation produces spinal antinociceptive actions via $\mathrm{D}_{2}$-like receptor selective mechanisms $[77,84,85]$.

\section{Mechanistic Appraisal of Potential Pharmacological Intervention beyond Dopamine $D_{2}$ Agonists}

\section{Opioid Receptors in RLS}

As is the case for $\mathrm{D}_{2}$-like receptors, activation of opioid receptors, which include the $\mu, \delta$, and $\kappa$ subtypes, results in $\mathrm{G}_{\mathrm{i}}$-coupled inhibition of adenylyl cyclase and cAMP formation in the postsynaptic neuron [86]. This signaling pathway mediates suppression of voltage-gated calcium currents and activation of outward potassium currents, resulting in hyperpolarization, reduced neurotransmitter release, inhibition of dorsal horn neurons, and depression of excitatory postsynaptic potentials $[87,88] . \mu, \delta$, and $\kappa$ opioid receptors are found in the spinal cord [89-93], in the dorsal and ventral horn [94-101], including on intrinsic neurons of the dorsal horn [87]. Opioid receptors are also expressed presynaptically on C-fiber primary afferents and in dorsal root ganglia (fig. 2) [90, 91, 102-104]. Expression of opioid receptors on sympathetic preganglionic neurons has been hypothesized [105], and there is evidence for it in the human spinal cord [106]. A rationale for opioid dysfunction in RLS has been proposed based on positron emission studies, which show reduced opioid-receptor availability in the medial affective pain system in the brain of patients with RLS and an inverse relationship between opioid receptor availability and severity of RLS [107]. Reduced opioid receptor availability may be a result of higher receptor occupancy by endogenous opioids, presumably via increased endogenous release of opioids, or opioid receptor downregulation and/or sequestration [107].

There are some data to support the concept that opioids improve the symptoms of RLS via indirect effects on the dopamine system [108]. Postsynaptic opioid receptor blockade with the opioid receptor antagonist naloxone reversed the effects of opioids but not dopamine agonists on RLS symptoms, while postsynaptic dopamine receptor blockade with dopamine receptor antagonist pimozide re- 
versed the effects of both dopamine agonists and opioids [108]. Taken together, available data suggest that the beneficial effects of opioids in RLS may be mediated by dopaminergic neurotransmission and thus not related to specific deficiencies of the endogenous opioid system [109].

\section{Adenosine Receptors in RLS}

Adenosine has been shown to play a role in motor activity and nociception [110, 111], and several adenosine receptor subtypes $\left(A_{1}, A_{2 A}, A_{2 B}\right.$, and $\left.A_{3}\right)$ are known to have opposing actions on cAMP formation; $A_{1}$ receptors couple with $G_{i}$ to inhibit and $A_{2}$ receptors to $G_{s}$ to stimulate formation of cAMP [112]. $A_{1}$ and $A_{2}$ receptors are expressed in the spinal cord [112-116], in dorsal horn neurons [114, 117-124], and the intermediolateral cell column (fig. 2) $[125,126] . A_{1}$ receptors are found in both excitatory and inhibitory cell bodies and processes in the inner part of lamina II of the dorsal horn, with lesser expression in primary afferent neurons [120].

Activation of the $A_{2 \mathrm{~A}}$ receptor increases inhibitory neurotransmission onto sympathetic preganglionic neurons and interneurons of the intermediolateral nucleus, while activation of the $A_{1}$ receptor decreases excitatory neurotransmission onto the same neurons [125]. Thus, activation of both $A_{2 A}$ and $A_{1}$ receptors would presumably result in inhibition of the postsynaptic neuron [125]. Similarly, activation of $A_{1}$ and $A_{2}$ receptors mediates spinal antinociception in an animal model of pain [127], and an $A_{1}$ receptor agonist reduced hyperalgesia following spinal cord injury [128]. Additionally, $\mathrm{A}_{2 \mathrm{~A}}$ receptors have been implicated in the development of neuropathic pain [129].

A functional link between adenosine and dopamine receptors has been reported in the brain [111]. In the striatum, $\mathrm{A}_{2 \mathrm{~A}}$ receptors form heterodimers with $\mathrm{D}_{2}$ receptors and may modulate dopaminergic activity by reducing the affinity of $\mathrm{D}_{2}$ receptors for dopamine, inhibiting $\mathrm{D}_{2}$-mediated signal transduction and presumably leading to modulation of striatal glutamatergic neurotransmission [39]. $A_{2 \mathrm{~A}}$ receptor antagonists could, therefore, potentiate the effects of $\mathrm{D}_{2}$ receptor agonists [39]. Similar interactions may occur elsewhere in the CNS including the spinal cord. More recently, data suggest that iron deficiency induces a functional upregulation of both striatal preand postsynaptic $A_{2 \mathrm{~A}}$ receptors [40].

The $\alpha_{2} \delta$ Calcium Channel Subunit and the Effects of Its Ligands on Sensory and Motor Neuromodulation

Voltage-gated calcium channels are multisubunit complexes composed of pore-forming $\alpha_{1}$ subunits and auxiliary $\alpha_{2} \delta, \beta$, and $\gamma$ subunits that regulate calcium flow into cells [130]. The $\alpha_{1}$ pore regulates passage of calcium into the cell, while the auxiliary subunits serve to modulate calcium channel expression and function [130]. Gabapentin and pregabalin are structurally analogous to the neurotransmitter gamma aminobutyric acid (GABA). Although several studies have shown agonist activity for gabapentin at $\mathrm{GABA}_{\mathrm{B}}$ receptors in a mouse pituitary intermediate melanotrope cell line [131], cortical slices [132], hippocampal neurons [133], and at recombinant $\mathrm{GABA}_{\mathrm{B}}$ receptors expressed in Xenopus laevis oocytes [133], others have failed to reproduce these findings and gabapentin and pregabalin do not appear to bind with high-affinity binding to these receptors [134-137]. Accumulating preclinical evidence indicates that gabapentin and pregabalin are selective, high-affinity ligands for the calcium channel $\alpha_{2} \delta$ subtype-1 protein and their effects are likely independent of $\mathrm{GABA}_{B}$ receptors $[130,134]$. The functional consequences of binding to the $\alpha_{2} \delta$ protein have been evaluated in multiple systems and in vivo systems [134, 138-140]. Such studies have pointed to a modulation in calcium flux at the nerve terminal in response to membrane depolarization that would result in a decrease in the release of excitatory neurotransmitters, such as glutamate and substance $P[134,141]$. Consistent with this hypothesis, a number of groups have demonstrated such effects of $\alpha_{2} \delta$ ligands on neurotransmitter release $[130,134,141]$. Gabapentin and pregabalin were also shown to reduce trafficking of $\alpha_{2} \delta$ subunits to the plasma membrane of presynaptic nerve terminals that results in fewer functional channels at the nerve terminal, which may be another mechanism by which $\alpha_{2} \delta$ ligands affect neurotransmitter release [130, 142, 143]. While these results followed chronic application of these drugs, it is conceivable that some of the immediate effects of $\alpha_{2} \delta$ ligands may be mediated by altered protein trafficking.

Unlike dopamine-, opioid-, and adenosine-receptor ligands, $\alpha_{2} \delta$ ligands do not require G-protein-coupled, cAMP-mediated second messenger pathways to exert their effects on voltage-gated calcium channels. $\alpha_{2} \delta$-containing calcium channels are found at various locations within the proposed RLS circuit (fig. 2), including the dorsal horn [144], dorsal root ganglia neurons [139, 142, 144-149], intermediolateral neurons [150], and sympathetic pre- and postganglionic neurons [151, 152]. Thus, they are in a prime position to control the excitability of the circuitry at the various points that may be involved in the symptomatology of RLS. Sympathetic spinal ganglia also express $\alpha_{2} \delta$ subunits [152]. Furthermore, expression of presynaptic $\alpha_{2} \delta$ subunits is induced by injury [146] and $\alpha_{2} \delta$ ligands inhibit voltage-gated channel activity in dor- 
sal root ganglia neurons [138] and reduce sympathetically maintained pain at the spinal level [151].

It is hypothesized from the results of preclinical studies that the binding of pregabalin to the $\alpha_{2} \delta$ subtype-1 protein causes a decrease in the release of synaptic vesicles at a variety of different synapses, including those that utilize substance $\mathrm{P}$, calcitonin gene-related peptide, and glutamate, which reduces subsequent postsynaptic neuronal firing. In certain disease states, such as neuropathic pain, abnormally intense neuronal firing is evident and this may be the case in RLS at the level of specific regions of the dorsal horn. Afferent overactivity could drive synaptogenesis, resulting in amplification of excitatory neurotransmission and overwhelming descending inhibition. More recent findings suggest that gabapentin and other $\alpha_{2} \delta$ ligands may act on neuronal processes that do not directly involve voltage-gated calcium channels such as the reduction of the expression of genes in the NF$\kappa \mathrm{B}$ pathway [153]. In addition, gabapentin was shown to block thrombospondin-mediated excitatory synapse formation in vitro and in vivo, which suggests that $\alpha_{2} \delta$ subtype-1 may function in synaptogenesis [154].

A recent series of articles has also proposed modulation of descending noradrenergic inhibitory pathways by gabapentin and pregabalin. It has been proposed from these preclinical studies that descending noradrenergic inhibitory pathways are facilitated by these $2 \alpha_{2} \delta$ ligands. These data suggest an additional direction in the mechanism of action of gabapentin and pregabalin in pain, and that their proposed spinal site of action includes amplification of descending inhibitory controls [155-158]. Pregabalin is proposed to reduce hyperexcitability in neuronal networks by binding to the $\alpha_{2} \delta$ protein and subsequently reducing neurotransmitter release, inhibiting aberrant excitatory synapse formation, and/or modulating descending inhibition. These may be the mechanisms by which pregabalin serves to modify the sensory-related symptoms of RLS and thus relieves the focal dysesthesias and the subsequent motor movements and sleep deprivation.

\section{Discussion}

RLS is a neurological disorder that has been studied for over 3 centuries. The known modulatory actions and sites of action of dopamine on spinal cord function can be used to physiologically explain the mechanisms of action of several potential therapies for RLS. We provide evidence that the potential therapeutic actions of $\mathrm{D}_{2}$-like agonists, opioids, and adenosine $\mathrm{A}_{2 \mathrm{~A}}$ antagonists converge on the common second messenger pathway of regulating G-protein-coupled cAMP formation, which results in neuronal hyperpolarization and reduced excitability. While localization of $\alpha_{2} \delta$-binding sites overlaps with those of $D_{2}$-like receptor agonists, $\alpha_{2} \delta$ ligands directly target voltagegated calcium channels and thus dampen sensory neurotransmission through reductions in excitatory neurotransmission. It is conceivable then that these new classes of pharmaceutical drugs may herald additional approaches that can relieve the symptoms of RLS.

\section{Acknowledgments}

This study was funded by Pfizer Inc. Editorial support was provided by Alison Gagnon, $\mathrm{PhD}$, of UBC Scientific Solutions and funded by Pfizer Inc. This review article contains information concerning a use of pregabalin and gabapentin that is not approved by the US Food and Drug Administration. A. Clair and A. Thorpe are full-time employees of Pfizer Inc. S. Hochman and S. Clemens served as paid consultants in an RLS advisory board meeting that was organized by Pfizer Inc.

\section{Note Added in Proof}

In April 2011 after acceptance of the manuscript, the U.S. Food and Drug Administration approved Horizant Extended Release Tablets (gabapentin enacarbil) for the treatment of moderate-tosevere primary Restless Legs Syndrome (RLS) in adults.

\section{References}

Therapeutic Sites of Action in RLS 
4 Willis T: Of diseases of the brain and genus nervosum; in Willis T: The London Practice of Physick. London, Bassett and Crooke, 1685.

$\checkmark 5$ Ekbom KA: Asthenia crurum pasasthetica (irritable legs). Acta Med Scand 1944;118: 197-209.

6 Ekbom KA: Restless legs syndrome. Acta Med Scand 1945;158(suppl):4-122.

$>7$ García-Borreguero D, Odin P, Schwarz C: Restless legs syndrome: an overview of the current understanding and management. Acta Neurol Scand 2004;109:303-317.

$\checkmark 8$ Clemens S, Rye D, Hochman S: Restless legs syndrome: revisiting the dopamine hypothesis from the spinal cord perspective. Neurology 2006;67:125-130.

>9 Trenkwalder C, Paulus W: Restless legs syndrome: pathophysiology, clinical presentation and management. Nat Rev Neurol 2010; 6:337-346.

10 Allen RP, Earley CJ: The role of iron in restless legs syndrome. Mov Disord 2007;22(suppl 18):S440-S448.

$\checkmark 11$ Unger EL, Earley CJ, Beard JL: Diurnal cycle influences peripheral and brain iron levels in mice. J Appl Physiol 2009;106:187-193.

12 Connor JR: Pathophysiology of restless legs syndrome: evidence for iron involvement. Curr Neurol Neurosci Rep 2008;8:162-166.

-13 Trenkwalder C, Hoegl B, Winkelmann J: Recent advances in the diagnosis, genetics and treatment of restless legs syndrome. J Neurol 2009;256:539-553.

- 14 Ondo WG, He Y, Rajasekaran S, Le WD: Clinical correlates of 6-hydroxydopamine injections into A11 dopaminergic neurons in rats: a possible model for restless legs syndrome. Mov Disord 2000;15:154-158.

$\checkmark 15$ Allen RP: Controversies and challenges in defining the etiology and pathophysiology of restless legs syndrome. Am J Med 2007; 120(suppl 1):S13-S21.

-16 Connor JR, Wang XS, Allen RP, Beard JL, Wiesinger JA, Felt BT, Earley CJ: Altered dopaminergic profile in the putamen and substantia nigra in restless leg syndrome. Brain 2009; 132:2403-2412.

- 17 Trenkwalder C, Hening WA, Montagna P, Oertel WH, Allen RP, Walters AS, Costa J, Stiasny-Kolster K, Sampaio C: Treatment of restless legs syndrome: an evidence-based review and implications for clinical practice. Mov Disord 2008;23:2267-2302.

- 18 Manconi M, Ferri R, Zucconi M, Oldani A, Fantini ML, Castronovo V, Ferini-Strambi L: First night efficacy of pramipexole in restless legs syndrome and periodic leg movements. Sleep Med 2007;8:491-497.

$\checkmark 19$ Happe S, Trenkwalder C: Role of dopamine receptor agonists in the treatment of restless legs syndrome. CNS Drugs 2004;18:27-36.

20 Kvernmo T, Härtter S, Burger E: A review of the receptor-binding and pharmacokinetic properties of dopamine agonists. Clin Ther 2006;28:1065-1078.
21 Newman-Tancredi A, Cussac D, Audinot V, Nicolas JP, De Ceuninck F, Boutin JA, Millan MJ: Differential actions of antiparkinson agents at multiple classes of monoaminergic receptor. II. Agonist and antagonist properties at subtypes of dopamine $\mathrm{D}_{2}$-like receptor and $\alpha_{1} / \alpha_{2}$-adrenoceptor. J Pharmacol Exp Ther 2002;303:805-814

-22 Scheller D, Ullmer C, Berkels R, Gwarek M, Lübbert $\mathrm{H}$ : The in vitro receptor profile of rotigotine: a new agent for the treatment of Parkinson's disease. Naunyn Schmiedebergs Arch Pharmacol 2009;379:73-86.

23 Tippmann-Peikert M, Park JG, Boeve BF, Shepard JW, Silber MH: Pathologic gambling in patients with restless legs syndrome treated with dopaminergic agonists. Neurology 2007;68:301-303.

24 Weintraub D, Siderowf AD, Potenza MN, Goveas J, Morales KH, Duda JE, Moberg PJ, Stern MB: Association of dopamine agonist use with impulse control disorders in Parkinson disease. Arch Neurol 2006;63:969973.

25 Davis BJ, Rajput A, Rajput ML, Aul EA, Eichhorn GR: A randomized, double-blind placebo-controlled trial of iron in restless legs syndrome. Eur Neurol 2000;43:70-75.

26 Wang J, O’Reilly B, Venkataraman R, Mysliwiec V, Mysliwiec A: Efficacy of oral iron in patients with restless legs syndrome and a low-normal ferritin: a randomized, doubleblind, placebo-controlled study. Sleep Med 2009;10:973-975

27 Sloand JA, Shelly MA, Feigin A, Bernstein P, Monk RD: A double-blind, placebo-controlled trial of intravenous iron dextran therapy in patients with ESRD and restless legs syndrome. Am J Kidney Dis 2004;43: 663-670.

28 Earley CJ, Heckler D, Allen RP: Repeated IV doses of iron provides effective supplementa treatment of restless legs syndrome. Sleep Med 2005;6:301-305.

29 Ondo WG: Intravenous iron dextran for severe refractory restless legs syndrome. Sleep Med 2010;11:494-496.

30 Earley CJ: The importance of oral iron therapy in restless legs syndrome. Sleep Med 2009;10:945-946.

31 Walters AS, Wagner ML, Hening WA, Grasing K, Mills R, Chokroverty S, Kavey N: Successful treatment of the idiopathic restless legs syndrome in a randomized double-blind trial of oxycodone versus placebo. Sleep 1993;16:327-332.

32 Lauerma H, Markkula J: Treatment of restless legs syndrome with tramadol: an open study. J Clin Psychiatry 1999;60:241-244.

33 Ondo WG: Methadone for refractory restless legs syndrome. Mov Disord 2005;20:345-348.

34 Silber MH, Ehrenberg BL, Allen RP, Buchfuhrer MJ, Earley CJ, Hening WA, Rye DB; Medical Advisory Board of the Restless Legs Syndrome Foundation: An algorithm for the management of restless legs syndrome. Mayo Clin Proc 2004;79:916-922.
35 Vignatelli L, Billiard M, Clarenbach P, Garcia-Borreguero D, Kaynak D, Liesiene V, Trenkwalder C, Montagna P; EFNS Task Force: EFNS guidelines on management of restless legs syndrome and periodic limb movement disorder in sleep. Eur J Neurol 2006;13:1049-1065.

$>36$ Vetrugno R, La Morgia C, D’Angelo R, Loi D, Provini F, Plazzi G, Montagna P: Augmentation of restless legs syndrome with long-term tramadol treatment. Mov Disord 2007;22: 424-427.

$\checkmark 37$ Yue HJ, Guilleminault C: Opioid medication and sleep-disordered breathing. Med Clin North Am 2010;94:435-446.

38 Walters AS, Winkelmann J, Trenkwalder C, Fry JM, Kataria V, Wagner M, Sharma R, Hening W, Li L: Long-term follow-up on restless legs syndrome patients treated with opioids. Mov Disord 2001;16:1105-1109.

39 Muller CE, Ferré S: Blocking striatal adenosine A2A receptors: a new strategy for basal ganglia disorders. Recent Pat CNS Drug Discov 2007;2:1-21.

40 Quiroz C, Pearson V, Gulyani S, Allen R, Earley C, Ferré S: Up-regulation of striatal adenosine $\mathrm{A}_{2 \mathrm{~A}}$ receptors with iron deficiency in rats. Effects on locomotion and cortico-striatal neurotransmission. Exp Neurol 2010;224:292-298

41 García-Borreguero D, Larrosa O, de la Llave Y, Verger K, Masramon X, Hernandez G: Treatment of restless legs syndrome with gabapentin: a double-blind, cross-over study. Neurology 2002;59:1573-1579.

42 Agarwal P, Griffith A, Costantino HR, Vaish N: Gabapentin enacarbil - clinical efficacy in restless legs syndrome. Neuropsychiatr Dis Treat 2010;6:151-158.

43 Kushida CA, Becker PM, Ellenbogen AL, Canafax DM, Barrett RW; XP052 Study Group: Randomized, double-blind, placebocontrolled study of XP13512/GSK1838262 in patients with RLS. Neurology 2009;72:439446 .

44 Kushida CA, Walters AS, Becker P, Thein SG, Perkins AT, Roth T, Canafax D, Barrett RW; XP021 Study Group: A randomized, double-blind, placebo-controlled, crossover study of XP13512/GSK1838262 in the treatment of patients with primary restless legs syndrome. Sleep 2009;32:159-168.

45 Walters AS, Ondo WG, Kushida CA, Becker PM, Ellenbogen AL, Canafax DM, Barrett RW; XP045 Study Group: Gabapentin enacarbil in restless legs syndrome: a phase $2 \mathrm{~b}$, 2-week, randomized, double-blind, placebocontrolled trial. Clin Neuropharmacol 2009; 32:311-320

46 Merlino G, Serafini A, Lorenzut S, Sommaro M, Gigli GL, Valente M: Gabapentin enacarbil in restless legs syndrome. Drugs Today (Barc) 2010;46:3-11. 
47 Sommer M, Bachmann CG, Liebetanz KM, Schindehütte J, Tings T, Paulus W: Pregabalin in restless legs syndrome with and without neuropathic pain. Acta Neurol Scand 2007;115:347-350.

-48 García-Borreguero D, Larrosa O, Williams AM, Albares J, Pascual M, Palacios JC, Fernandez C: Treatment of restless legs syndrome with pregabalin: a double-blind, placebo-controlled study. Neurology 2010;74: 1897-1904.

-49 Allen R, Chen C, Soaita A, Wohlberg C, Knapp L, Peterson BT, García-Borreguero D, Miceli J: A randomized, double-blind, 6-week, dose-ranging study of pregabalin in patients with restless legs syndrome. Sleep Med 2010;11:512-519.

-50 Bogan RK, Bornemann MA, Kushida CA, Trân PV, Barrett RW; XP060 Study Group: Long-term maintenance treatment of restless legs syndrome with gabapentin enacarbil: a randomized controlled study. Mayo Clin Proc 2010;85:512-521.

-51 Hochman S: Spinal cord. Current Biology 2007;17:R950-R955.

52 Kuhar MJ, Couceyro PR, Lambert PD: Catecholamines; in Siegel GJ, Agranoff BW, Albers RW, Fisher SK, Uhler MD (eds): Basic Neurochemistry: Molecular, Cellular and Medical Aspects. Philadelphia, PA, Lippincott Williams \& Wilkins, 1999, ed 3, pp 243-262.

53 Holstege JC, Van Dijken H, Buijs RM, Goedknegt H, Gosens T, Bongers CM: Distribution of dopamine immunoreactivity in the rat, cat and monkey spinal cord. J Comp Neurol 1996;376:631-652.

-54 Zhu H, Clemens S, Sawchuk M, Hochman S: Expression and distribution of all dopamine receptor subtypes $\left(D_{1}-D_{5}\right)$ in the mouse lumbar spinal cord: a real-time polymerase chain reaction and non-autoradiographic in situ hybridization study. Neuroscience 2007; 149:885-897.

55 Cavallotti C, Frati A, Cavallotti D, Tranquilli Leali FM: Dopaminergic receptors in rat dura mater: pharmacological characteristics. Clin Exp Pharmacol Physiol 2004;31: 190-194.

56 van Dijken H, Dijk J, Voom P, Holstege JC: Localization of dopamine $\mathrm{D} 2$ receptor in rat spinal cord identified with immunocytochemistry and in situ hybridization. Eur J Neurosci 1996;8:621-628.

57 Levant B, McCarson KE: $D_{3}$ dopamine receptors in rat spinal cord: implications for sensory and motor function. Neurosci Lett 2001;303:9-12.

58 Matsumoto M, Hidaka K, Akiho H, Tada S, Okada M, Yamaguchi T: Low stringency hybridization study of the dopamine D4 receptor revealed D4-like mRNA distribution of the orphan seven-transmembrane receptor, APJ, in human brain. Neurosci Lett 1996; 219:119-122.
59 Wamsley JK, Gehlert DR, Filloux FM, Dawson TM: Comparison of the distribution of D-1 and D-2 dopamine receptors in the rat brain. J Chem Neuroanat 1989;2:119-137.

-60 Barraud Q, Obeid I, Aubert I, Barriere G, Contamin H, McGuire S, Ravenscroft P, Porras G, Tison F, Bezard E, Ghorayeb I: Neuroanatomical study of the A11 diencephalospinal pathway in the non-human primate. PLoS One 2010;5:e13306.

-61 Pivonello R, Ferone D, Lombardi G, Colao A Lamberts SW, Hofland LJ: Novel insights in dopamine receptor physiology. Eur J Endocrinol 2007;156(suppl 1):S13-S21.

62 Paulus W, Dowling P, Rijsman R, StiasnyKolster K, Trenkwalder C, de Weerd A: Pathophysiological concepts of restless legs syndrome. Mov Disord 2007;22:1451-1456.

63 Skagerberg G, Lindvall O: Organization of diencephalic dopamine neurones projecting to the spinal cord in the rat. Brain Res 1985; 342:340-351.

64 Qu S, Ondo WG, Zhang X, Xie WJ, Pan TH, Le WD: Projections of diencephalic dopamine neurons into the spinal cord in mice. Exp Brain Res 2006;168:152-156.

65 Carlsson A, Svennerholm L, Winblad B: Seasonal and circadian monoamine variations in human brains examined post mortem. Acta Psychiatr Scand Suppl 1980;280:75-85.

66 Qu S, Le W, Zhang X, Xie W, Zhang A, Ondo WG: Locomotion is increased in A11-lesioned mice with iron deprivation: a possible animal model for restless legs syndrome. J Neuropathol Exp Neurol 2007;66:383-388.

67 Earley CJ, Allen RP, Connor JR, Ferrucci L, Troncoso J: The dopaminergic neurons of the A11 system in RLS autopsy brains appear normal. Sleep Med 2009; 10:1155-1157.

68 Hofman MA: The human circadian clock and aging. Chronobiol Int 2000;17:245-259.

-69 Weinert D: Age-dependent changes of the circadian system. Chronobiol Int 2000;17: 261-283.

70 Earley CJ, Hyland K, Allen RP: Circadian changes in CSF dopaminergic measures in restless legs syndrome. Sleep Med 2006;7: 263-268.

71 Clemens S, Sawchuk MA, Hochman S: Reversal of the circadian expression of tyrosine-hydroxylase but not nitric oxide synthase levels in the spinal cord of dopamine $\mathrm{D}_{3}$ receptor knockout mice. Neuroscience 2005; 133:353-357.

72 Taepavarapruk N, Taepavarapruk P, John J, Lai YY, Siegel JM, Phillips AG, McErlane SA, Soja PJ: State-dependent changes in glutamate, glycine, GABA, and dopamine levels in cat lumbar spinal cord. J Neurophysiol 2008;100:598-608.

73 Bara-Jimenez W, Aksu M, Graham B, Sato S, Hallett M: Periodic limb movements in sleep: state-dependent excitability of the spinal flexor reflex. Neurology 2000;54:16091616.
74 Trenkwalder C, Hening WA, Walters AS, Campbell SS, Rahman K, Chokroverty S: Circadian rhythm of periodic limb movements and sensory symptoms of restless legs syndrome. Mov Disord 1999;14:102-110.

75 Xie GX, Jones K, Peroutka SJ, Palmer PP: Detection of mRNAs and alternatively spliced transcripts of dopamine receptors in rat peripheral sensory and sympathetic ganglia. Brain Res 1998;785:129-135.

76 Molokanova EA, Tamarova ZA: The effects of dopamine and serotonin on rat dorsal root ganglion neurons: an intracellular study. Neuroscience 1995;65:859-867.

77 Fleetwood-Walker SM, Hope PJ, Mitchell R: Antinociceptive actions of descending dopaminergic tracts on cat and rat dorsal horn somatosensory neurones. J Physiol 1988;399: 335-348.

78 Pappas SS, Behrouz B, Janis KL, Goudreau JL, Lookingland KJ: Lack of D2 receptor mediated regulation of dopamine synthesis in $\mathrm{A}_{11}$ diencephalospinal neurons in male and female mice. Brain Res 2008;1214:1-10.

79 Accili D, Fishburn CS, Drago J, Steiner H, Lachowicz JE, Park BH, Gauda EB, Lee EJ, Cool MH, Sibley DR, Gerfen CR, Westphal $\mathrm{H}$, Fuchs S: A targeted mutation of the $\mathrm{D}_{3}$ dopamine receptor gene is associated with hyperactivity in mice. Proc Natl Acad Sci USA 1996;93:1945-1949.

-80 Asico LD, Ladines C, Fuchs S, Accili D, Carey RM, Semeraro C, Pocchiari F, Felder RA, Eisner GM, Jose PA: Disruption of the dopamine $\mathrm{D}_{3}$ receptor gene produces renin-dependent hypertension. J Clin Invest 1998; 102:493-498.

81 Ondo WG, Zhao HR, Le WD: Animal models of restless legs syndrome. Sleep Med 2007; 8:344-348.

82 Dowling $\mathrm{P}$, Klinker F, Stadelmann C, Hasan K, Paulus W, Liebetanz D: Dopamine D3 receptor specifically modulates motor and sensory symptoms in iron-deficient mice. J Neurosci 2011;31:70-77.

83 Clemens S, Hochman S: Conversion of the modulatory actions of dopamine on spinal reflexes from depression to facilitation in $\mathrm{D}_{3}$ receptor knock-out mice. J Neurosci 2004; 24:11337-11345.

84 Charbit AR, Akerman S, Holland PR, Goadsby PJ: Neurons of the dopaminergic/calcitonin gene-related peptide A11 cell group modulate neuronal firing in the trigeminocervical complex: an electrophysiological and immunohistochemical study. J Neurosci 2009;29:12532-12541.

-85 Taniguchi W, Nakatsuka T, Miyazaki N, Yamada H, Takeda D, Fujita T, Kumamoto E, Yoshida M: In vivo patch-clamp analysis of dopaminergic antinociceptive actions on substantia gelatinosa neurons in the spinal cord. Pain 2011;152:95-105.

86 Connor M, Christie MD: Opioid receptor signalling mechanisms. Clin Exp Pharmacol Physiol 1999;26:493-499. 
87 Dougherty PM, Staats PS: Intrathecal drug therapy for chronic pain: from basic science to clinical practice. Anesthesiology 1999;91: 1891-1918.

-88 Williams JT, Christie MJ, Manzoni O: Cellular and synaptic adaptations mediating opioid dependence. Physiol Rev 2001;81:299-343.

-89 George SR, Zastawny RL, Briones-Urbina R, Cheng R, Nguyen T, Heiber M, Kouvelas A, Chan AS, O'Dowd BF: Distinct distributions of $\mathrm{mu}$, delta and kappa opioid receptor mRNA in rat brain. Biochem Biophys Res Commun 1994;205:1438-1444.

-90 Ji RR, Zhang Q, Law PY, Low HH, Elde R, Hökfelt T: Expression of $\mu$-, $\delta$-, and $\kappa$-opioid receptor-like immunoreactivities in rat dorsal root ganglia after carrageenan-induced inflammation. J Neurosci 1995;15:81568166.

-91 Mansour A, Fox CA, Burke S, Meng F, Thompson RC, Akil H, Watson SJ: Mu, delta, and kappa opioid receptor mRNA expression in the rat CNS: an in situ hybridization study. J Comp Neurol 1994;350:412-438.

-92 Peckys D, Landwehrmeyer GB: Expression of mu, kappa, and delta opioid receptor messenger RNA in the human CNS: a ${ }^{33} \mathrm{P}$ in situ hybridization study. Neuroscience 1999;88: 1093-1135

$\checkmark 93$ Morinville A, Cahill CM, Aibak H, Rymar VV, Pradhan A, Hoffert C, Mennicken F, Stroh T, Sadikot AF, O'Donnell D, Clarke PB, Collier B, Henry JL, Vincent JP, Beaudet A: Morphine-induced changes in $\delta$ opioid receptor trafficking are linked to somatosensory processing in the rat spinal cord. J Neurosci 2004;24:5549-5559.

-94 Gouardères C, Cros J, Quirion R: Autoradiographic localization of mu, delta and kappa opioid receptor binding sites in rat and guinea pig spinal cord. Neuropeptides 1985;6: 331-342.

$>95$ Honda CN, Arvidsson U: Immunohistochemical localization of delta- and mu-opioid receptors in primate spinal cord. Neuroreport 1995;6:1025-1028.

$\checkmark 96$ Schäfer MK, Bette M, Romeo H, Schwaeble W, Weihe E: Localization of kappa-opioid receptor mRNA in neuronal subpopulations of rat sensory ganglia and spinal cord. Neurosci Lett 1994;167:137-140.

-97 Zhang Y, Pan YX, Kolesnikov Y, Pasternak GW: Immunohistochemical labeling of the mu opioid receptor carboxy terminal splice variant mMOR-1B4 in the mouse central nervous system. Brain Res 2006;1099:33-43.

98 Ray SB, Wadhwa S: Expression of mu-opioid receptors in developing rat spinal cord: an autoradiographic study. Indian J Exp Biol 2004;42:533-537.

$\checkmark 99$ Abbadie C, Pasternak GW, Aicher SA: Presynaptic localization of the carboxy-terminus epitopes of the $\mu$ opioid receptor splice variants MOR-1C and MOR-1D in the superficial laminae of the rat spinal cord. Neuroscience $2001 ; 106: 833-842$.
100 Ray SB, Wadhwa S: Mu opioid receptors in developing human spinal cord. J Anat 1999; 195:11-18.

101 Ding YQ, Kaneko T, Nomura S, Mizuno N: Immunohistochemical localization of muopioid receptors in the central nervous system of the rat. J Comp Neurol 1996;367: 375-402.

102 Abbadie C, Lombard MC, Besson JM, Trafton JA, Basbaum AI: Mu and delta opioid receptor-like immunoreactivity in the cervical spinal cord of the rat after dorsal rhizotomy or neonatal capsaicin: an analysis of pre- and postsynaptic receptor distributions. Brain Res 2002;930:150-162.

103 Scherrer G, Imamachi N, Cao YQ, Contet C, Mennicken F, O'Donnell D, Kieffer BL, Basbaum AI: Dissociation of the opioid receptor mechanisms that control mechanical and heat pain. Cell 2009;137:1148-1159.

104 Bi J, Tsai NP, Lin YP, Loh HH, Wei LN: Axonal mRNA transport and localized translational regulation of $\kappa$-opioid receptor in primary neurons of dorsal root ganglia. Proc Natl Acad Sci USA 2006;103. 19919-19924.

105 Stein C, Clark JD, Oh U, Vasko MR, Wilcox GL, Overland AC, Vanderah TW, Spencer RH: Peripheral mechanisms of pain and analgesia. Brain Res Rev 2009;60:90-113.

106 Faull RL, Villiger JW: Opiate receptors in the human spinal cord: a detailed anatomical study comparing the autoradiographic localization of $\left[{ }^{3} \mathrm{H}\right]$ diprenorphine binding sites with the laminar pattern of substance $\mathrm{P}$, myelin and nissl staining. Neuroscience 1987;20:395-407.

107 von Spiczak S, Whone AL, Hammers A Asselin MC, Turkheimer F, Tings T, Happe S, Paulus W, Trenkwalder C, Brooks DJ: The role of opioids in restless legs syndrome: an $\left[{ }^{11} \mathrm{C}\right]$ diprenorphine PET study. Brain 2005; 128:906-917.

108 Walters AS: Review of receptor agonist and antagonist studies relevant to the opiate system in restless legs syndrome. Sleep Med 2002;3:301-304.

109 Barrière G, Cazalets JR, Bioulac B, Tison F, Ghorayeb I: The restless legs syndrome. Prog Neurobiol 2005;77:139-165.

110 Sosnowski M, Stevens CW, Yaksh TL: Assessment of the role of A1/A2 adenosine receptors mediating the purine antinociception, motor and autonomic function in the rat spinal cord. J Pharmacol Exp Ther 1989; 250:915-922.

111 Aoyama S, Kase H, Borrelli E: Rescue of locomotor impairment in dopamine D2 receptor-deficient mice by an adenosine A2A receptor antagonist. J Neurosci 2000;20: 5848-5852.

112 Choca JI, Proudfit HK, Green RD: Identification of $\mathrm{A} 1$ and $\mathrm{A} 2$ adenosine receptors in the rat spinal cord. J Pharmacol Exp Ther 1987;242:905-910.
113 Lee HG, Kim WM, Choi JI, Yoon MH: Roles of adenosine receptor subtypes on the antinociceptive effect of sildenafil in rat spinal cord. Neurosci Lett 2010;480: 182-185.

114 Reppert SM, Weaver DR, Stehle JH, Rivkees SA: Molecular cloning and characterization of a rat A1-adenosine receptor that is widely expressed in brain and spinal cord. Mol Endocrinol 1991;5:1037-1048.

115 Sumida T, Smith MA, Maehara Y, Collins JG, Kitahata LM: Spinal R-phenyl-isopropyl adenosine inhibits spinal dorsal horn neurons responding to noxious heat stimulation in the absence and presence of sensitization. Pain 1998;74:307-313.

116 Yoon MH, Choi JI, Jeong SW: Spinal gabapentin and antinociception: mechanisms of action. J Korean Med Sci 2003;18:255-261.

117 Choca JI, Green RD, Proudfit HK: Adenosine A1 and A2 receptors of the substantia gelatinosa are located predominantly on intrinsic neurons: an autoradiography study. J Pharmacol Exp Ther 1988;247:757-764.

$>118$ Lao LJ, Kawasaki Y, Yang K, Fujita T, Kumamoto E: Modulation by adenosine of Adelta and C primary-afferent glutamatergic transmission in adult rat substantia gelatinosa neurons. Neuroscience 2004; 125: 221-231.

119 Lao LJ, Kumamoto E, Luo C, Furue H, Yoshimura M: Adenosine inhibits excitatory transmission to substantia gelatinosa neurons of the adult rat spinal cord through the activation of presynaptic $A_{1}$ adenosine receptor. Pain 2001;94:315-324.

120 Schulte G, Robertson B, Fredholm BB, DeLander GE, Shortland P, Molander C: Distribution of antinociceptive adenosine $\mathrm{A}_{1}$ receptors in the spinal cord dorsal horn, and relationship to primary afferents and neuronal subpopulations. Neuroscience 2003;121:907-916.

121 Tian L, Ji G, Wang C, Bai X, Lu Y, Xiong L: Excitatory synaptic transmission in the spinal substantia gelatinosa is under an inhibitory tone of endogenous adenosine. Neurosci Lett 2010;477:28-32.

122 Wu L, Li H, Li YQ: Adenosine suppresses the response of neurons to GABA in the superficial laminae of the rat spinal dorsal horn. Neuroscience 2003;119:145-154.

123 Guntz E, Dumont H, Pastijn E, d'Exaerde Ade K, Azdad K, Sosnowski M, Schiffmann SN, Gall D: Expression of adenosine $\mathrm{A}_{2 \mathrm{~A}}$ receptors in the rat lumbar spinal cord and implications in the modulation of $N$-methyl-d-aspartate receptor currents. Anesth Analg 2008;106:1882-1889.

124 Weaver DR: A1-adenosine receptor gene expression in fetal rat brain. Brain Res Dev Brain Res 1996;94:205-223.

125 Brooke RE, Deuchars J, Deuchars SA: Input-specific modulation of neurotransmitter release in the lateral horn of the spinal cord via adenosine receptors. J Neurosci 2004;24:127-137. 
-126 Peng SC, Ho CM, Ho ST, Tsai SK, Su CK: The role of intraspinal adenosine $\mathrm{A}_{1}$ receptors in sympathetic regulation. Eur J Pharmacol 2004;492:49-55.

127 Sawynok J, Sweeney MI, White TD: Classification of adenosine receptors mediating antinociception in the rat spinal cord. Br J Pharmacol 1986;88:923-930.

-128 Horiuchi H, Ogata T, Morino T, Yamamoto $\mathrm{H}$ : Adenosine $\mathrm{A} 1$ receptor agonists reduce hyperalgesia after spinal cord injury in rats. Spinal Cord 2010;48:685-690.

-129 Bura SA, Nadal X, Ledent C, Maldonado R, Valverde $\mathrm{O}: \mathrm{A}_{2 \mathrm{~A}}$ adenosine receptor regulates glia proliferation and pain after peripheral nerve injury. Pain 2008;140:95-103.

130 Thorpe AJ, Offord J: The alpha2-delta protein: an auxiliary subunit of voltage-dependent calcium channels as a recognized drug target. Curr Opin Investig Drugs 2010;11:761-770.

- 131 Bertrand S, Ng GY, Purisai MG, Wolfe SE, Severidt MW, Nouel D, Robitaille R, Low MJ, O’Neill GP, Metters K, Lacaille JC, Chronwall BM, Morris SJ: The anticonvulsant, antihyperalgesic agent gabapentin is an agonist at brain gamma-aminobutyric acid type $B$ receptors negatively coupled to voltage-dependent calcium channels. J Pharmacol Exp Ther 2001;298:15-24.

-132 Parker DA, Ong J, Marino V, Kerr DI: Gabapentin activates presynaptic GABAB heteroreceptors in rat cortical slices. Eur J Pharmacol 2004;495:137-143.

-133 Ng GY, Bertrand S, Sullivan R, Ethier N, Wang J, Yergey J, Belley M, Trimble L, Bateman K, Alder L, Smith A, McKernan R, Metters K, O’Neill GP, Lacaille JC, Hebert TE: Gamma-aminobutyric acid type B receptors with specific heterodimer composition and postsynaptic actions in hippocampal neurons are targets of anticonvulsant gabapentin action. Mol Pharmacol 2001;59:144-152.

-134 Taylor CP, Angelotti T, Fauman E: Pharmacology and mechanism of action of pregabalin: the calcium channel $\alpha_{2} \delta$ (alpha $_{2^{-}}$ delta) subunit as a target for antiepileptic drug discovery. Epilepsy Res 2007;73:137150 .

-135 Cheng JK, Lee SZ, Yang JR, Wang CH, Liao YY, Chen CC, Chiou LC: Does gabapentin act as an agonist at native $\mathrm{GABA}(\mathrm{B})$ receptors? J Biomed Sci 2004; 11:346-355.

136 Jensen AA, Mosbacher J, Elg S, Lingenhoehl K, Lohmann T, Johansen TN, Abrahamsen B, Mattsson JP, Lehmann A, Bettler B, Brauner-Osborne $\mathrm{H}$ : The anticonvulsant gabapentin (neurontin) does not act through gamma-aminobutyric acid-B receptors. Mol Pharmacol 2002;61:13771384.

-137 Lanneau C, Green A, Hirst WD, Wise A, Brown JT, Donnier E, Charles KJ, Wood M, Davies $\mathrm{CH}$, Pangalos MN: Gabapentin is not a GABAB receptor agonist. Neuropharmacology 2001;41:965-975.
138 Hendrich J, Van Minh AT, Heblich F, Nieto-Rostro M, Watschinger K, Striessnig J, Wratten J, Davies A, Dolphin AC: Pharmacological disruption of calcium channel trafficking by the $\alpha_{2} \delta$ ligand gabapentin. Proc Natl Acad Sci USA 2008;105:36283633.

139 Alden KJ, García J: Differential effect of gabapentin on neuronal and muscle calcium currents. J Pharmacol Exp Ther 2001; 297:727-735

140 Joshi I, Taylor CP: Pregabalin action at a model synapse: binding to presynaptic calcium channel $\alpha_{2}-\delta$ subunit reduces neurotransmission in mice. Eur J Pharmacol 2006;553:82-88.

141 Dooley DJ, Taylor CP, Donevan S, Feltner $\mathrm{D}$ : $\mathrm{Ca}^{2+}$ channel $\alpha_{2} \delta$ ligands: novel modulators of neurotransmission. Trends Pharmacol Sci 2007;28:75-82.

142 Bauer CS, Nieto-Rostro M, Rahman W, Tran-Van-Minh A, Ferron L, Douglas L, Kadurin I, Sri Ranjan Y, Fernandez-Alacid L, Millar NS, Dickenson AH, Lujan R, Dolphin AC: The increased trafficking of the calcium channel subunit $\alpha_{2} \delta-1$ to presynaptic terminals in neuropathic pain is inhibited by the $\alpha_{2} \delta$ ligand pregabalin. J Neurosci 2009;29:4076-4088.

143 Mich PM, Horne WA: Alternative splicing of the $\mathrm{Ca}^{2+}$ channel $\beta 4$ subunit confers specificity for gabapentin inhibition of $\mathrm{Ca}_{\mathrm{v}} 2.1$ trafficking. Mol Pharmacol 2008; 74:904-912.

144 Taylor CP, Garrido R: Immunostaining of rat brain, spinal cord, sensory neurons and skeletal muscle for calcium channel alpha $_{2}$-delta $\left(\alpha_{2}-\delta\right)$ type 1 protein. Neuroscience 2008;155:510-521.

145 Cole RL, Lechner SM, Williams ME, Prodanovich P, Bleicher L, Varney MA, Gu G: Differential distribution of voltage-gated calcium channel alpha-2 delta $\left(\alpha_{2} \delta\right)$ subunit mRNA-containing cells in the rat central nervous system and the dorsal root ganglia. J Comp Neurol 2005;491:246269.

146 Li CY, Song YH, Higuera ES, Luo ZD: Spinal dorsal horn calcium channel $\alpha_{2} \delta$-1 subunit upregulation contributes to peripheral nerve injury-induced tactile allodynia. J Neurosci 2004;24:8494-8499.

147 Li YN, Li YC, Kuramoto H, Liu ZR, Kawate T, Atsumi S, Deng YC, Huang YG: Immunohistochemical demonstration of the calcium channel $\alpha 2$ subunit in the chicken dorsal root ganglion and spinal cord: a special reference to colocalization with calbindin-D28k in dorsal root ganglion neurons. Neurosci Res 2007;59:304-308.

148 Newton RA, Bingham S, Case PC, Sanger GJ, Lawson SN: Dorsal root ganglion neurons show increased expression of the calcium channel $\alpha 2 \delta$-1 subunit following partial sciatic nerve injury. Brain Res Mol Brain Res 2001;95:1-8.
149 Yusaf SP, Goodman J, Pinnock RD, Dixon AK, Lee K: Expression of voltage-gated calcium channel subunits in rat dorsal root ganglion neurons. Neurosci Lett 2001;311: 137-141.

150 Rabchevsky AG, Patel SP, Duale H, Lyttle TS, O’Dell CR, Kitzman PH: Gabapentin for spasticity and autonomic dysreflexia after severe spinal cord injury. Spinal Cord 2011;49:99-105.

151 Han DW, Kweon TD, Lee JS, Lee YW: Antiallodynic effect of pregabalin in rat models of sympathetically maintained and sympathetic independent neuropathic pain. Yonsei Med J 2007;48:41-47.

152 Ivanov SV, Ward JM, Tessarollo L, McAreavey D, Sachdev V, Fananapazir L, Banks MK, Morris N, Djurickovic D, Devor-Henneman DE, Wei MH, Alvord GW, Gao B, Richardson JA, Minna JD, Rogawski MA, Lerman MI: Cerebellar ataxia, seizures, premature death, and cardiac abnormalities in mice with targeted disruption of the Cacna2d2 gene. Am J Pathol 2004; 165:1007-1018.

153 Park S, Ahn ES, Han DW, Lee JH, Min KT, Kim H, Hong YW: Pregabalin and gabapentin inhibit substance P-induced NF- $\mathrm{BB}$ activation in neuroblastoma and glioma cells. J Cell Biochem 2008;105:414-423.

154 Eroglu C, Allen NJ, Susman MW, O’Rourke NA, Park CY, Ozkan E, Chakraborty C, Mulinyawe SB, Annis DS, Huberman AD, Green EM, Lawler I, Dolmetsch R, Garcia KC, Smith SJ, Luo ZD, Rosenthal A, Mosher DF, Barres BA: Gabapentin receptor $\alpha 2 \delta-1$ is a neuronal thrombospondin receptor responsible for excitatory CNS synaptogenesis. Cell 2009;139:380-392.

155 Rahman W, Bauer CS, Bannister K, Vonsy JL, Dolphin AC, Dickenson AH: Descending serotonergic facilitation and the antinociceptive effects of pregabalin in a rat model of osteoarthritic pain. Mol Pain 2009;5:45.

156 Takeuchi Y, Takasu K, Ono H, Tanabe M: Pregabalin, S-(+)-3-isobutylgaba, activates the descending noradrenergic system to alleviate neuropathic pain in the mouse partial sciatic nerve ligation model. Neuropharmacology 2007;53:842-853.

157 Tanabe M, Takasu K, Kasuya N, Shimizu S, Honda M, Ono H: Role of descending noradrenergic system and spinal $\alpha 2$-adrenergic receptors in the effects of gabapentin on thermal and mechanical nociception after partial nerve injury in the mouse. $\mathrm{Br} \mathrm{J}$ Pharmacol 2005;144:703-714

158 Tanabe M, Takasu K, Takeuchi Y, Ono H: Pain relief by gabapentin and pregabalin via supraspinal mechanisms after peripheral nerve injury. J Neurosci Res 2008;86: 3258-3264. 